Article

\title{
Estimating Hantavirus Risk in Southern Argentina: A GIS-Based Approach Combining Human Cases and Host Distribution
}

Veronica Andreo $^{1, *}$, Markus Neteler ${ }^{2}$, Duccio Rocchini ${ }^{2}$, Cecilia Provensal ${ }^{3}$, Silvana Levis ${ }^{4}$, Ximena Porcasi ${ }^{1}$, Annapaola Rizzoli ${ }^{2}$, Mario Lanfri ${ }^{1}$, Marcelo Scavuzzo ${ }^{1}$, Noemi Pini ${ }^{4}$, Delia Enria $^{4}$ and Jaime Polop ${ }^{3}$

1 Instituto de Altos Estudios Espaciales “Mario Gulich”, Centro Espacial Teófilo Tabanera, CONAE, Ruta Provincial C45, Km 8, Falda del Carmen, Córdoba 5187, Argentina;

E-Mails: ximena.porcasi@conae.gov.ar (X.P.); lamfri@conae.gov.ar (M.L.); scavuzzo@conae.gov.ar (M.S.)

2 GIS and Remote Sensing Unit and Animal Ecology Unit, Department of Biodiversity and Molecular Ecology, Research and Innovation Center, Fondazione Edmund Mach, Via E. Mach 1, San Michele all'Adige, Trento 38010, Italy; E-Mails: markus.neteler@fmach.it (M.N.); duccio.rocchini@fmach.it (D.R.); annapaola.rizzoli@fmach.it (A.R.)

3 Departamento de Ciencias Naturales, Universidad Nacional de Río Cuarto, Ruta 36 Km 601, Agencia Postal N 3, Río Cuarto, Córdoba 5800, Argentina; E-Mails: cprovensal@exa.unrc.edu.ar (C.P.); jpolop@exa.unrc.edu.ar (J.P.)

4 Instituto Nacional de Enfermedades Virales Humanas “Dr. Julio I. Maiztegui” (INEVH), Monteagudo 2510, Pergamino, Buenos Aires 2700, Argentina; E-Mails: slevis0@yahoo.com (S.L.); pininoemi@yahoo.com.ar (N.P.); deliaenria@gmail.com (D.E.)

* Author to whom correspondence should be addressed; E-Mail: veroandreo@gmail.com; Tel.: +54-354-743-1000.

Received: 30 October 2013; in revised form: 17 December 2013 / Accepted: 18 December 2013 / Published: 14 January 2014

Abstract: We use a Species Distribution Modeling (SDM) approach along with Geographic Information Systems (GIS) techniques to examine the potential distribution of hantavirus pulmonary syndrome (HPS) caused by Andes virus (ANDV) in southern Argentina and, more precisely, define and estimate the area with the highest infection probability for humans, through the combination with the distribution map for the competent rodent host (Oligoryzomys longicaudatus). Sites with confirmed cases of HPS 
in the period 1995-2009 were mostly concentrated in a narrow strip $(\sim 90 \mathrm{~km} \times 900 \mathrm{~km})$ along the Andes range from northern Neuquén to central Chubut province. This area is characterized by high mean annual precipitation $(\sim 1,000 \mathrm{~mm}$ on average $)$, but dry summers (less than $100 \mathrm{~mm})$, very low percentages of bare soil $(\sim 10 \%$ on average) and low temperatures in the coldest month (minimum average temperature $-1.5{ }^{\circ} \mathrm{C}$ ), as compared to the HPS-free areas, features that coincide with sub-Antarctic forests and shrublands (especially those dominated by the invasive plant Rosa rubiginosa), where rodent host abundances and ANDV prevalences are known to be the highest. Through the combination of predictive distribution maps of the reservoir host and disease cases, we found that the area with the highest probability for HPS to occur overlaps only $28 \%$ with the most suitable habitat for $O$. longicaudatus. With this approach, we made a step forward in the understanding of the risk factors that need to be considered in the forecasting and mapping of risk at the regional/national scale. We propose the implementation and use of thematic maps, such as the one built here, as a basic tool allowing public health authorities to focus surveillance efforts and normally scarce resources for prevention and control actions in vast areas like southern Argentina.

Keywords: Argentina; Oligoryzomys longicaudatus; Andes virus (ANDV); hantavirus pulmonary syndrome (HPS); Species Distribution Models (SDM); Geographic Information Systems (GIS); risk

\section{Introduction}

Hantavirus pulmonary syndrome (HPS), an acute respiratory illness fatal in $10 \%-50 \%$ of cases [1], is a severe disease caused by viruses of the Bunyaviridae family. These viruses are zoonotic, host-specific RNA-viruses that persistently infect murid or cricetid rodents of the subfamilies, Murinae, Arvicolinae, Neotominae and Sigmodontinae [2]. Hantaviruses are also known to be carried by shrews, moles and bats [3-5]. To date, at least 43 hantavirus genotypes have been described, and about half of them are known to cause HPS in humans [2,6]. Each hantavirus is usually hosted by a single host species in which it establishes a chronic, asymptomatic infection that involves the shedding of infectious virus into the environment in host urine, feces and saliva. These characteristics are key to the transmission of the virus to humans and among rodents [7-10].

Researchers have long acknowledged that the dynamics of a host population and its relationship with the environmental conditions determine the extent to which a pathogen may persist or disappear, therefore affecting the transmission risk for humans [11,12]. If the chain of relationships, known as the trophic cascade hypothesis, holds true $[13,14]$, we would be able to predict transmission risk to humans from climatic and environmental features of sites with confirmed cases of a certain zoonotic disease [12]. The trophic cascade model was originally proposed to explain the number of plague and HPS human cases in the southwestern USA $[13,14]$. The authors hypothesized that high precipitation (mediated by El Niño phenomenon) increases plant productivity, which, in turn, increases the rodent density. Higher rodent densities lead to higher contact rates, a higher probability of contact with humans and a higher 
probability of transmission. This model was originally thought of for temporal dynamics, but if we think of it as taking place in the spatial dimension, we may assume that all these relationships occur in every point (or cell) of the space and, consequently, determine the distribution and abundance of hosts, pathogens and human cases of the disease.

Vector-borne and zoonotic diseases display clear spatial patterns that relate to different space-dependent factors: (a) the spatial distribution of vectors and reservoir hosts; (b) the pathogen dispersal ability (conditioned by host or vector dispersal, landscape configuration, etc.) and; (c) the human exposure to the infectious agent [15]. In that context, Geographical Information Systems (GIS) and remote sensing (RS) may represent proper tools to describe the spatial distribution of infectious diseases and predict disease risk. These tools have already been used to explain or predict tick-borne [16] and rodent-borne diseases [17-19], relating spatial data on land cover and climate to the ecology of the vector or hosts. Species distribution models (SDM) help to delineate the specific habitat requirements of a species [20,21]; coupled with GIS and RS tools, these models can be extrapolated to produce maps displaying the spatial configuration of suitable habitats [22]. These maps are a basic tool for many aspects of resource management and conservation planning [22,23].

How does a trophic cascade relate to SDM? In our view, the trophic cascade model described above may be considered a movie, a temporal film; and SDM for host, pathogen and disease cases as screen-shots of that movie, instantaneous pictures that are the result of environment-host-human interactions. Therefore, if we assume that the number of human cases is related to the density of host (higher density, higher probability of virus transmission among hosts and from hosts to humans) and that this latter issue is determined by physical and biological environmental conditions and we model the relationship between hosts and environment or directly between human cases and the environment, we can predict and map those areas with a higher probability of disease occurrence [12].

In Argentina, four distinct HPS-endemic areas have been recognized [24-26]: Northwest (Salta, Jujuy and Formosa provinces), Northeast (Misiones Province), Central (Buenos Aires, Santa Fe and Entre Ríos provinces) and Southern (Neuquén, Río Negro, Chubut and Santa Cruz provinces). These regions differ in their landscape types, vegetation types, agricultural production and land management practices. Hantavirus strains and reservoir hosts differ among endemic areas, and HPS cases are unevenly distributed in space and time in the four regions. The mouse, Oligoryzomys longicaudatus (Bennet, 1832), commonly known as colilargo, is the reservoir of Andes virus (ANDV), the hantavirus responsible for HPS in southern Argentina and Chile [27,28]. The colilargo is a widespread rodent highly abundant in the woods and shrublands in Chile and southwestern Argentina [19,29-34]. However, it has also been captured in the steppe and in disturbed habitats, such as the borders of cultivated fields, peridomestic settings and pastures [32,33]. The species presents seasonal changes in abundances [33] and irregular outbreaks ("ratadas") that have been related to bamboo blooming and masting events [35,36]. Besides, the population dynamics of colilargos has been related to precipitations and global climatic indexes [37,38]. Antibody prevalence rates in O. longicaudatus show spatial and temporal variations, reaching values of almost 50\% in some springs [10,31-33,39]. During disease outbreaks, lethality has reached levels of $\sim 50 \%$ [40]. In addition to its virulence, ANDV epidemiology is slightly complicated by occasional person-to-person transmission, a feature unique to this particular hantavirus strain [41-43]. These aspects make the understanding of the system as a whole an issue of particular relevance for public health. 
The relationship of the environment to HPS occurrence is a recent topic of study in Argentina. Hence, if ecological factors affect the distribution of HPS and these factors can be identified, models can be developed to predict the potential distribution of yet unknown foci. Therefore, given the lethality of the disease and the possibility of human-to-human transmission in southern Argentina, it is of great interest to identify and explain the environmental variables associated with HPS case occurrence in order to recognize and predict those places where the risk is higher, allowing public health authorities to focus surveillance efforts and concentrate resources where the need is greatest. Previous works have already assessed the distribution of O. longicaudatus in Argentina [19,44,45]. Here, we model and map the distribution of HPS cases caused by ANDV in southern Argentina, to determine the relationship between case occurrence and environmental variables and, more precisely, define and estimate the area with the highest infection probability for humans, through the combination with the distribution map for the rodent host [19].

\section{Results}

From 1995 to 2009, a total of 149 HPS cases were confirmed in southern Argentina as being caused by ANDV. The great majority of them were concentrated in the Andean region of Neuquén, Río Negro and Chubut provinces (40, 54 and 54, respectively). The cases occurred mostly in forest habitats (between $30 \%$ and $60 \%$, according to the classification scheme considered) with shrublands in second place (15\%-25\%, according to the classification considered). The only case registered in Santa Cruz province occurred in a steppe habitat and constitutes the southernmost confirmed case in Argentina (occurring $>800 \mathrm{~km}$ from the core endemic area of Patagonia).

Sites with and without HPS cases by ANDV (Figure 1) differ significantly for most of the environmental variables considered (Table 1). Most precipitation related variables showed a positive association with HPS occurrence, while temperature related ones showed a negative association with case distribution (Table 1).

The best multivariate binomial generalized linear models (GLM) in terms of Akaike's information criterion (AIC) ( $\mathrm{m} 1$ and $\mathrm{m} 2$, Table 2), included the percent of bare soil (bare), isothermality (bio3), minimum temperature of the coldest month (bio6), mean annual precipitation (bio12) and precipitation of the warmest and coldest seasons (bio18 and bio19, respectively). Variables bare, bio3 and bio18 were negatively associated with the probability of HPS, while bio6, bio12 and bio19 showed a positive relationship. The model with the lowest AIC (m1) was spatialized and selected to draw inferences. In the Maximum Entropy (MaxEnt) model (run with the same predictors as $\mathrm{m} 1$ ), environmental variables showed the same general pattern of association with HPS occurrence, although bio6, bio12 and bio18 presented non-lineal relationships. 
Figure 1. Training and test samples for the occurrence of hantavirus pulmonary syndrome (HPS) in Argentina. Training data in circles; test data in triangles. Filled symbols are the presence and empty symbols the absence of occurrence.

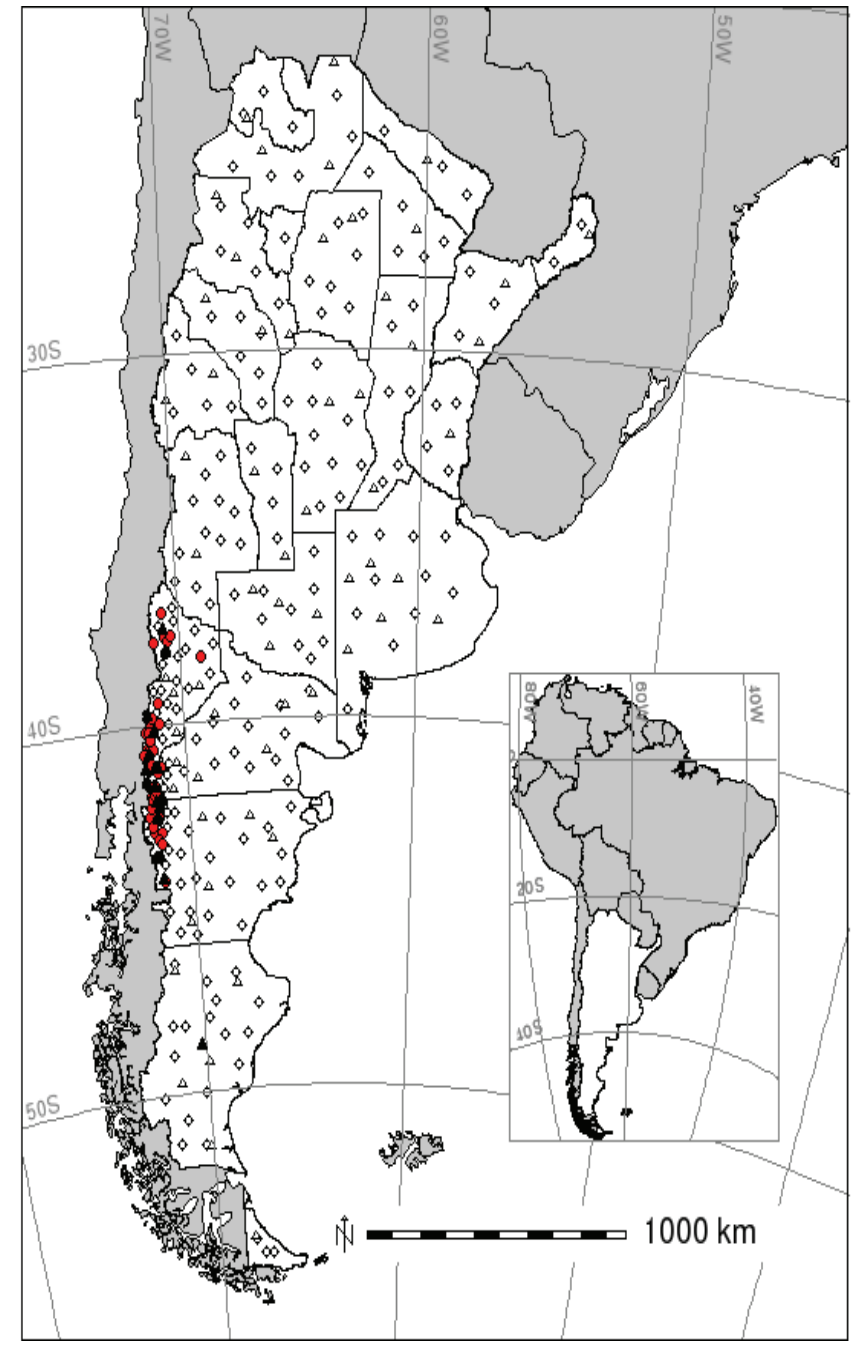

Distribution maps (GLM and MaxEnt) for HPS in southern Argentina (Figure 2) showed a high probability area in a narrow strip along the Andes range (approximately $90 \mathrm{~km}$ in the widest part and almost $900 \mathrm{~km}$ long) from the northwest of Neuquén to the center of Chubut province. The GLM predictive map shows two other "high probability" areas, where no cases by ANDV have ever been reported: Valdés peninsula (Chubut) and Samborombón bay (Buenos Aires). Besides, it shows moderate or moderate-high probability areas in some other places of the Atlantic coast (southern Buenos Aires, north-central Río Negro, south-central Chubut and northern Santa Cruz), where, to the best of our knowledge, no cases have been ever declared. On the other hand, the predictive map obtained with MaxEnt extends (discontinuously) the moderate-high probability area until the southwest of Santa Cruz and Tierra del Fuego provinces along the Andes range. The great majority of confirmed cases occurred in the high probability area in both predictive maps, except for a few of them in the north and east of Neuquén province and the only case of Santa Cruz province (Figure 2). 
Table 1. Univariate statistics for the environmental variables considered in sites with and without HPS cases by Andes virus in southern Argentina.

\begin{tabular}{|c|c|c|c|c|c|c|c|}
\hline Variable & Description and units & HPS & Mean & SD & Median & $\mathbf{K}$ & $\mathbf{B}$ \\
\hline \multirow{2}{*}{ ALT } & Elevation above sea level & 0 & 739.39 & 825.78 & 518.50 & \multirow{2}{*}{$4,364.5 * * *$} & \multirow{2}{*}{$0.000018 \mathrm{~ns}$} \\
\hline & $(\mathrm{m})$ & 1 & 749.03 & 358.73 & 726.00 & & \\
\hline \multirow{2}{*}{ BARE } & Percentage of bare soil cover & 0 & 34.26 & 33.94 & 26.00 & \multirow{2}{*}{$8,506 * * *$} & \multirow{2}{*}{$-0.0447 * * *$} \\
\hline & $(\%)$ & 1 & 7.51 & 14.46 & 0.00 & & \\
\hline \multirow{2}{*}{ HERB } & Percentage of grass cover & 0 & 56.13 & 29.12 & 61.00 & \multirow{2}{*}{$5,991.5 \mathrm{~ns}$} & \multirow{2}{*}{$-0.0024 \mathrm{~ns}$} \\
\hline & $(\%)$ & 1 & 54.28 & 23.18 & 59.00 & & \\
\hline \multirow{2}{*}{ TREE } & Percentage of tree cover & 0 & 9.61 & 15.65 & 3.00 & \multirow{2}{*}{$1,909.5 * * *$} & \multirow{2}{*}{$0.05215 * * *$} \\
\hline & $(\%)$ & 1 & 38.21 & 28.50 & 32.00 & & \\
\hline \multirow{2}{*}{$\mathrm{BIO} 1$} & Annual mean temperature & 0 & 131.02 & 53.56 & 135.50 & \multirow{2}{*}{$8,256 * * *$} & \multirow{2}{*}{$-0.0217 * * *$} \\
\hline & $\left(\mathrm{x} * 10,{ }^{\circ} \mathrm{C}\right)$ & 1 & 89.00 & 15.34 & 89.00 & & \\
\hline \multirow{2}{*}{$\mathrm{BIO} 2$} & Mean diurnal range & 0 & 135.33 & 19.65 & 136.50 & \multirow{2}{*}{$7,854 * * *$} & \multirow{2}{*}{$-0.0308 * * *$} \\
\hline & (Mean month (max-min), in ${ }^{\circ} \mathrm{C}$ ) & 1 & 125.31 & 12.61 & 123.00 & & \\
\hline \multirow{2}{*}{$\mathrm{BIO} 3$} & Isothermality & 0 & 49.91 & 3.82 & 49.00 & \multirow{2}{*}{$3,203.5 * * *$} & \multirow{2}{*}{$0.13419 * *$} \\
\hline & $((\mathrm{BIO} 2 / \mathrm{BIO} 7) * 100)$ & 1 & 51.66 & 1.87 & 52.00 & & \\
\hline \multirow{2}{*}{$\mathrm{BIO} 4$} & Temperature seasonality & 0 & $4,817.7$ & 691.50 & $4,823.0$ & 872 & - \\
\hline & $(\mathrm{S} L$ & 1 & $4,284.7$ & 317.77 & $4,248.0$ & 8,14 & - \\
\hline & Maximum temp of the warmest month & 0 & 273.58 & 60.68 & 296.00 & & \\
\hline BIO5 & $\left(\mathrm{x} * 10,{ }^{\circ} \mathrm{C}\right)$ & 1 & 228.61 & 23.10 & 224.00 & $8,334.5 * \cdots$ & $-0.0153 * *+20$ \\
\hline & Minimum temp of the coldest month & 0 & 5.10 & 43.74 & 1.50 & & \\
\hline BIU6 & $\left(\mathrm{x} * 10,{ }^{\circ} \mathrm{C}\right)$ & 1 & -11.46 & 10.41 & -11.00 & $.5 \times \cdots$ & -1 \\
\hline BIO7 & Temperature annual range (BIO5-BIO6) & 0 & 268.48 & 35.24 & 270.00 & & $0302 *$ \\
\hline BIO/ & $\left(\mathrm{x} * 10,{ }^{\circ} \mathrm{C}\right)$ & 1 & 240.07 & 18.52 & 237.00 & $8, / 49 \cdots$ & $-0.0302 \times$ \\
\hline & Mean temp of the wettest quarter & 0 & 141.24 & 95.40 & 152.00 & & \\
\hline $\mathrm{BlO} 8$ & $\left(\mathrm{x} * 10,{ }^{\circ} \mathrm{C}\right)$ & 1 & 39.57 & 15.67 & 41.00 & ** & -0.02 \\
\hline & Mean temp of the driest quarter & 0 & 112.47 & 39.82 & 109.50 & & \\
\hline $\mathrm{BIO9}$ & $\left(\mathrm{x} * 10,{ }^{\circ} \mathrm{C}\right)$ & 1 & 143.26 & 18.64 & 142.00 & 2,96 & 0.0 \\
\hline BIO10 & Mean temp of the warmest quarter & 0 & 191.63 & 56.51 & 203.00 & $5105 * * *$ & $-00201 * * *$ \\
\hline BIUI0 & $\left(\mathrm{x} * 10,{ }^{\circ} \mathrm{C}\right)$ & 1 & 144.44 & 18.17 & 143.00 & איד & -0.0201 \\
\hline BIO11 & Mean temp of the coldest quarter & 0 & 68.54 & 51.69 & 69.00 & & $0.0201 * * *$ \\
\hline ВIOI & $\left(\mathrm{x} * 10,{ }^{\circ} \mathrm{C}\right)$ & 1 & 34.49 & 12.78 & 35.00 & & $0.0201 \cdots *$ \\
\hline & Annual precipitation & 0 & 494.92 & 338.62 & 402.50 & & \\
\hline BIO12 & $(\mathrm{mm})$ & 1 & 976.97 & 309.86 & $1,011.0$ & 1,7 & 0.00386 \\
\hline RIO13 & Precipitation of the wettest month & 0 & 75.13 & 48.68 & 63.50 & $11825 * * *$ & $00351 * * *$ \\
\hline BIU13 & $(\mathrm{mm})$ & 1 & 168.69 & 52.52 & 170.00 &, $182.5 \cdots$ & 0.035 \\
\hline & Precipitation of the driest month & 0 & 15.34 & 14.54 & 11.00 & 8355 & 00623 \\
\hline BIO14 & $(\mathrm{mm})$ & 1 & 28.67 & 11.41 & 26.00 & , 835.5 & 0.0623 \\
\hline & Precipitation seasonality & 0 & 48.94 & 23.73 & 45.50 & & \\
\hline BIO15 & (variation coefficient) & 1 & 58.02 & 7.70 & 58.00 & (נ) & $0.0200 * *$ \\
\hline & Precipitation of the wettest quarter & 0 & 201.12 & 131.03 & 177.50 & 108 & $* * *$ \\
\hline BIU & $(\mathrm{mm})$ & 1 & 455.36 & 131.42 & 476.00 & $1,081 \cdots \cdots$ & bres \\
\hline BIO17 & Precipitation of the driest quarter & 0 & 54.09 & 49.44 & 40.00 & $7285 * * *$ & $002017 * * *$ \\
\hline 017 & $(\mathrm{~mm})$ & 1 & 105.52 & 40.98 & 101.00 & & $0.0201 / 7.0$ \\
\hline $\mathrm{BIO}$ & Precipitation of the warmest quarter & 0 & 151.59 & 128.00 & 88.00 & & $-0.00410 * *$ \\
\hline BIO & & 1 & 105.84 & 41.44 & 101.00 & $5,584 \mathrm{~ns}$ & \\
\hline BIO19 & Precipitation of the coldest quarter & 0 & 94.67 & 98.46 & 56.00 & $438 * * *$ & $0.0159 * * *$ \\
\hline & $(\mathrm{mm})$ & 1 & 431.13 & 129.22 & 451.00 & & \\
\hline
\end{tabular}

BARE: \% of bare soil cover; HERB: \% of grass cover; TREE: \% of woody cover; HPS (0): HPS absence; HPS (1): HPS presence; SD: standard deviation; K: Kruskal-Wallis chi-squared statistic; B: univariate binomial Generalized Linear Model parameter (parameter significance according to a $t$-test on parameter SD with 245 degrees of freedom); ${ }^{* * *} p<0.001 ;{ }^{*} p<0.01 ;{ }^{*} p<0.05 ; p<0.1$; ns: not significant, $p>0.1$. 
Table 2. Multivariate binomial GLM models for HPS by Andes virus occurrence in southern Argentina.

\begin{tabular}{|c|c|c|c|}
\hline Model & Variables & AIC & $\Delta \mathbf{A I C}$ \\
\hline $\mathrm{m} 1$ & $\mathrm{BARE}+\mathrm{BIO} 3+\mathrm{BIO} 6+\mathrm{BIO} 18+\mathrm{BIO} 12$ & 76.07 & 0.00 \\
\hline $\mathrm{m} 2$ & $\mathrm{BARE}+\mathrm{BIO} 3+\mathrm{BIO} 6+\mathrm{BIO} 18+\mathrm{BIO} 19$ & 76.76 & 0.69 \\
\hline $\mathrm{m} 3$ & $\mathrm{BARE}+\mathrm{BIO} 3+\mathrm{BIO} 6+\mathrm{BIO} 18+\mathrm{BIO} 19+\mathrm{TREE}$ & 78.32 & 2.25 \\
\hline $\mathrm{m} 4$ & $\mathrm{BIO} 3+\mathrm{BIO} 6+\mathrm{BIO} 12+\mathrm{BIO} 18$ & 79.79 & 3.71 \\
\hline $\mathrm{m} 5$ & $\mathrm{BARE}+\mathrm{BIO} 3+\mathrm{BIO} 4+\mathrm{BIO} 6+\mathrm{BIO} 18+\mathrm{BIO} 19+\mathrm{TREE}$ & 79.86 & 3.78 \\
\hline $\mathrm{m} 6$ & $\mathrm{BIO} 3+\mathrm{BIO} 4+\mathrm{BIO} 6+\mathrm{BIO} 12+\mathrm{BIO} 18$ & 80.69 & 4.62 \\
\hline $\mathrm{m} 7$ & $\mathrm{BIO} 3+\mathrm{BIO} 6+\mathrm{BIO} 18+\mathrm{BIO} 19+\mathrm{TREE}$ & 80.71 & 4.63 \\
\hline $\mathrm{m} 8$ & $\mathrm{HERB}+\mathrm{BIO} 3+\mathrm{BIO} 6+\mathrm{BIO} 18+\mathrm{BIO} 12$ & 81.45 & 5.38 \\
\hline $\mathrm{m} 9$ & $\mathrm{BARE}+\mathrm{BIO} 3+\mathrm{BIO} 4+\mathrm{BIO} 6+\mathrm{BIO} 15+\mathrm{BIO} 18+\mathrm{BIO} 19+\mathrm{TREE}$ & 81.86 & 5.78 \\
\hline $\mathrm{m} 10$ & $\mathrm{BIO} 9+\mathrm{BIO} 19$ & 88.12 & 12.04 \\
\hline $\mathrm{m} 11$ & $\mathrm{BIO} 12+\mathrm{BIO} 19$ & 98.20 & 22.13 \\
\hline $\mathrm{m} 12$ & $\mathrm{BIO} 4+\mathrm{BIO} 19$ & 100.42 & 24.35 \\
\hline
\end{tabular}

BARE: \% of bare soil cover; HERB: \% of grass cover; TREE: \% of woody cover; BIO1: Mean annual temperature; BIO3: Isothermality; BIO4: Temperature seasonality; BIO6: Minimum temperature of the coldest month; BIO9: Mean temperature of the dry season; BIO12: Mean annual precipitation; BIO15: Precipitation seasonality; BIO18: Precipitation of the warmest quarter; BIO19: Precipitation of the coldest quarter; AIC: Akaike's information criterion value; $\triangle \mathrm{AIC}$ : difference between each model AIC and the one of the lowest AIC.

Figure 2. Predicted potential geographic distribution of HPS caused by Andes virus (ANDV) in southern Argentina. (a) binomial generalized linear model; (b) Maximum Entropy (MaxEnt) model.

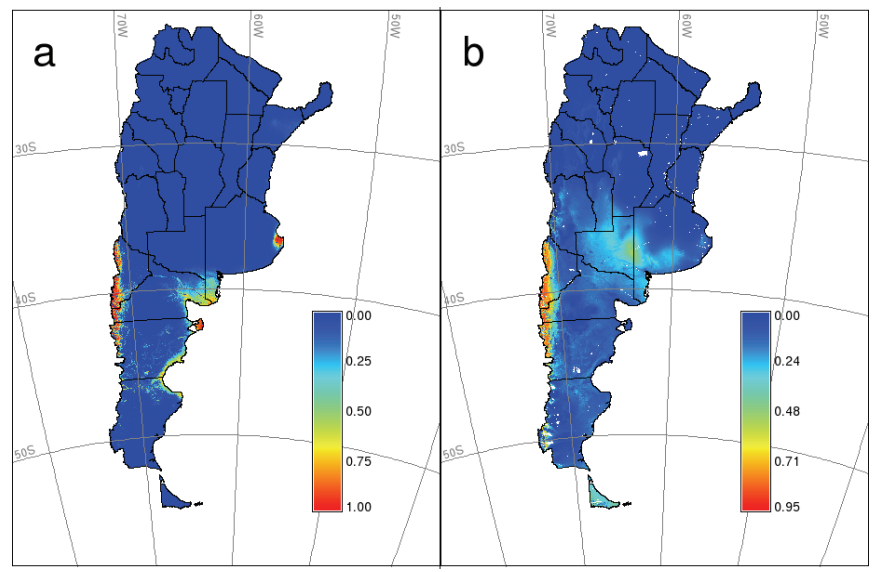

According to receiver operating characteristic (ROC) curves and area under the curve (AUC) values, both models had highly satisfactory performances (0.986 and 0.984, for GLM and MaxEnt models, respectively). However, in the threshold-dependent approach (Table 3), differences in predictive performance between models were more noticeable, especially when considering minimum occurrence prediction as the threshold. These differences were then translated to presence-absence maps (not shown). After analyzing accuracy and error measures for different threshold-selection criteria, the best cut-off probabilities were 0.43 and 0.65 for GLM and MaxEnt models, respectively. 
As the threshold 0.65 for the MaxEnt model showed the best performance in key indexes, like sensitivity and false negative rate (Table 3), we used this predictive map for further analysis. The binary map built using this threshold (0.65) is shown in Figure 3a. The same analysis was carried out for the host predictive model (not shown), and the resulting binary map is shown in Figure $3 b$ (cut-off probability for MaxEnt model $=0.52$ ). To complement the assessment of the HPS model's predictive performance, we used the threshold-independent ROC curve and AUC on test samples. Again, models behaved nearly equally: AUC of 0.986 and 0.975 , for GLM and MaxEnt models, respectively.

Table 3. Comparison of the models' performance using different criteria for threshold selection. All criteria in the last line for generalized linear model (GLM) and maximum entropy algorithm (MaxEnt) predictions yielded the same cut-off probability. Min, minimum; Sens, sensitivity; Specif, specificity; Max, maximum; Max prop correct, maximum proportion of presence and absence records correctly identified; K, Kappa index; ROC, receiver operating characteristic.

\begin{tabular}{|c|c|c|c|c|c|c|c|c|}
\hline Criteria & Threshold & Sensitivity & Specificity & $\begin{array}{c}\text { False } \\
\text { positive } \\
\text { rate } \\
\end{array}$ & $\begin{array}{c}\text { False } \\
\text { negative } \\
\text { rate }\end{array}$ & $\begin{array}{c}\text { Positive } \\
\text { predictive } \\
\text { value } \\
\end{array}$ & $\begin{array}{c}\text { Negative } \\
\text { predictive } \\
\text { value } \\
\end{array}$ & $\mathbf{K}$ \\
\hline \multicolumn{9}{|l|}{ GLM } \\
\hline $\begin{array}{l}\text { Min occurrence } \\
\text { prediction }\end{array}$ & 0.019 & 1.000 & 0.742 & 0.258 & 0.000 & 0.560 & 1.00 & 0.59 \\
\hline $\begin{array}{c}\text { Mean occurrence } \\
\text { prediction }\end{array}$ & 0.869 & 0.754 & 0.989 & 0.011 & 0.246 & 0.958 & 0.925 & 0.80 \\
\hline $10 \%$ omission & 0.550 & 0.902 & 0.962 & 0.038 & 0.098 & 0.887 & 0.968 & 0.86 \\
\hline Sens $=$ Specif, Max & & & & & & & & \\
\hline $\begin{array}{c}\text { Sens }+ \text { Specif, Max } \\
\text { prop correct, Max } \\
\text { K, Min ROC plot } \\
\text { distance } \\
\end{array}$ & 0.430 & 0.951 & 0.952 & 0.048 & 0.049 & 0.866 & 0.983 & 0.87 \\
\hline \multicolumn{9}{|l|}{ MaxEnt } \\
\hline $\begin{array}{c}\text { Min occurrence } \\
\text { prediction }\end{array}$ & 0.093 & 1.000 & 0.505 & 0.495 & 0.000 & 0.399 & 1.000 & 0.33 \\
\hline $\begin{array}{c}\text { Mean occurrence } \\
\text { prediction }\end{array}$ & 0.799 & 0.738 & 0.989 & 0.011 & 0.262 & 0.957 & 0.920 & 0.79 \\
\hline $10 \%$ omission & 0.730 & 0.902 & 0.968 & 0.032 & 0.098 & 0.902 & 0.968 & 0.87 \\
\hline Sens $=$ Specif & 0.570 & 0.951 & 0.952 & 0.048 & 0.049 & 0.866 & 0.983 & 0.87 \\
\hline $\begin{array}{l}\text { Max Sens+Specif, } \\
\text { Max prop correct, } \\
\text { Max K, Min ROC } \\
\text { plot distance }\end{array}$ & 0.650 & 0.951 & 0.968 & 0.032 & 0.049 & 0.906 & 0.984 & 0.90 \\
\hline
\end{tabular}

Figure 3c,d show the reclassified maps for HPS and rodent host distribution that were built considering the best thresholds estimated in each case and the analysis of the distribution of predicted probabilities for the presence and absence points in the training datasets. The resulting reclassification rules for mice and HPS were: (1) for mice occurrence: $0.0-0.3=1 ; 0.3-0.5=2 ; 0.5-0.7=3$ and $0.7-1.0=4$; and (2) for HPS occurrence: $0.0-0.35=1 ; 0.35-0.6=2 ; 0.6-0.75=3$; 
$0.75-1.0=4$. The value (1) represents very low or null risk; (2) low risk; (3) moderate risk and (4) high risk.

Figure 3. MaxEnt binary (above) and reclassified (below) maps for HPS cases by ANDV and $O$. longicaudatus presence in southern Argentina. (a,c) HPS by ANDV; (b,d) O. longicaudatus.

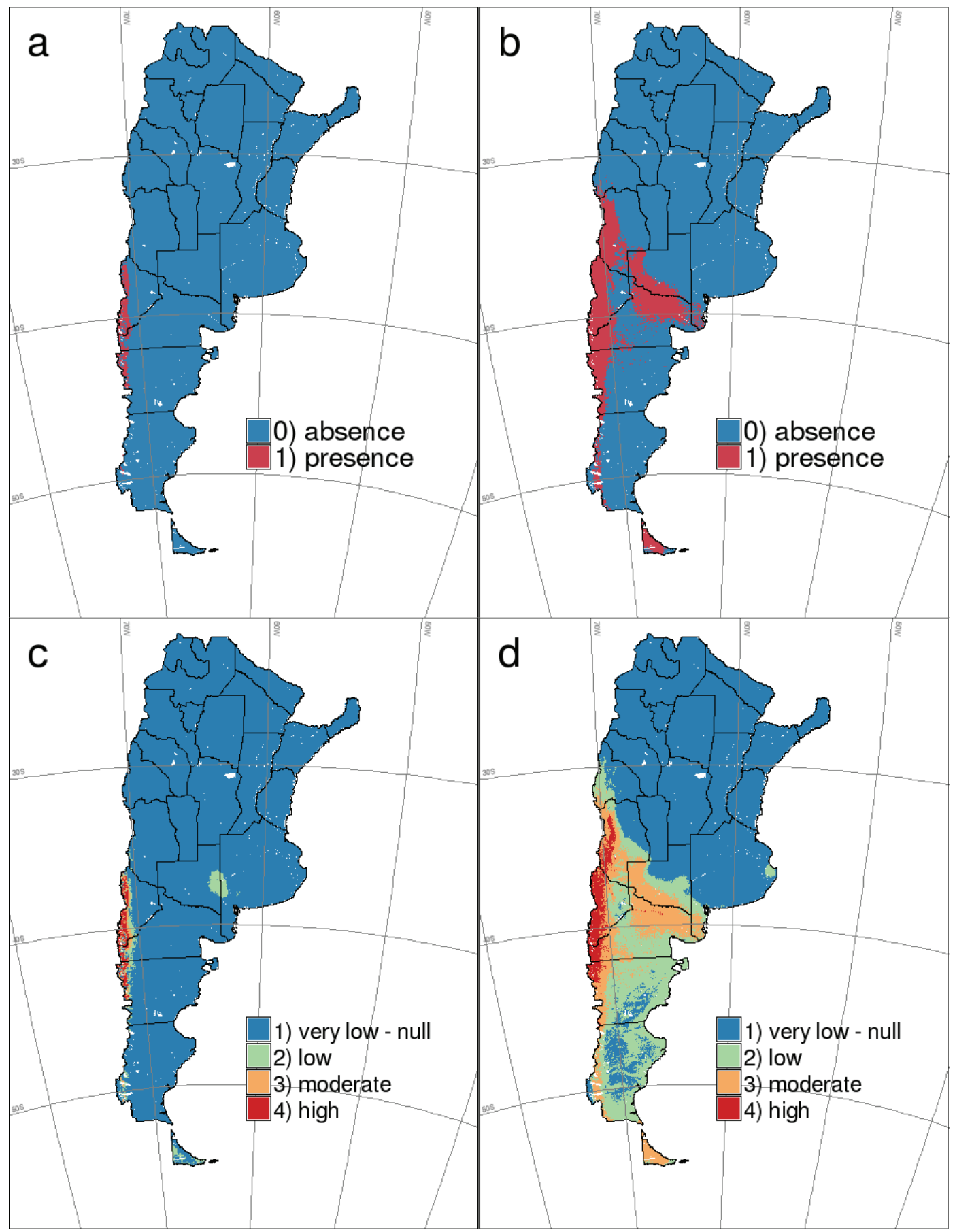

Overall, the area that resulted in being classified as HPS-positive according to the 0.65 threshold covers a surface of almost $38,000 \mathrm{~km}^{2}$, while the predicted area for the host presence $(0.52$ threshold) 
encompasses approximately $353,000 \mathrm{~km}^{2}$. Therefore, according to the estimated presence thresholds, the actual distribution of the disease comprises an $\sim 11 \%$ of the distribution of the reservoir host. When we consider the reclassified maps, the area with the highest probability of HPS occurrence covers approximately $23,500 \mathrm{~km}^{2} ; 28 \%$ of the area where the probability of finding the rodent host is the highest (Figure 3c,d).

The risk map resulting from combining reclassified maps for host and HPS case distributions is shown in Figure 4. Risk, as well as occurrence probabilities for the host and the disease decreases more or less generally from west to east and from north to south. The highest risk area (class 6), the one combining a high probability of both mice and human disease case occurrences and where most HPS confirmed cases occurred, covers approximately $22,000 \mathrm{~km}^{2}$ (700 km in length and $70 \mathrm{~km}$ in width). In terms of the type of habitat, this area corresponds to sub-Antarctic Nothofagus and Austrocedrus forests and shrublands. There are some other disjunctive patches classified as high and moderate-high risk in southwestern Chubut and northwestern Santa Cruz provinces, also characterized by this type of habitats. Then, there is a low risk area along Colorado river, where no HPS cases have been confirmed; but, it has a moderate probability of $O$. longicaudatus occurrence, and only two cases were recorded in areas classified as very low risk (Figure 4b), areas that are steppe habitats.

Figure 4. (a) Risk map for HPS caused by Andes virus in southern Argentina; (b) zoomed map of Patagonia covering HPS occurrence. Training (black circles) and test (white triangles) HPS presence records.

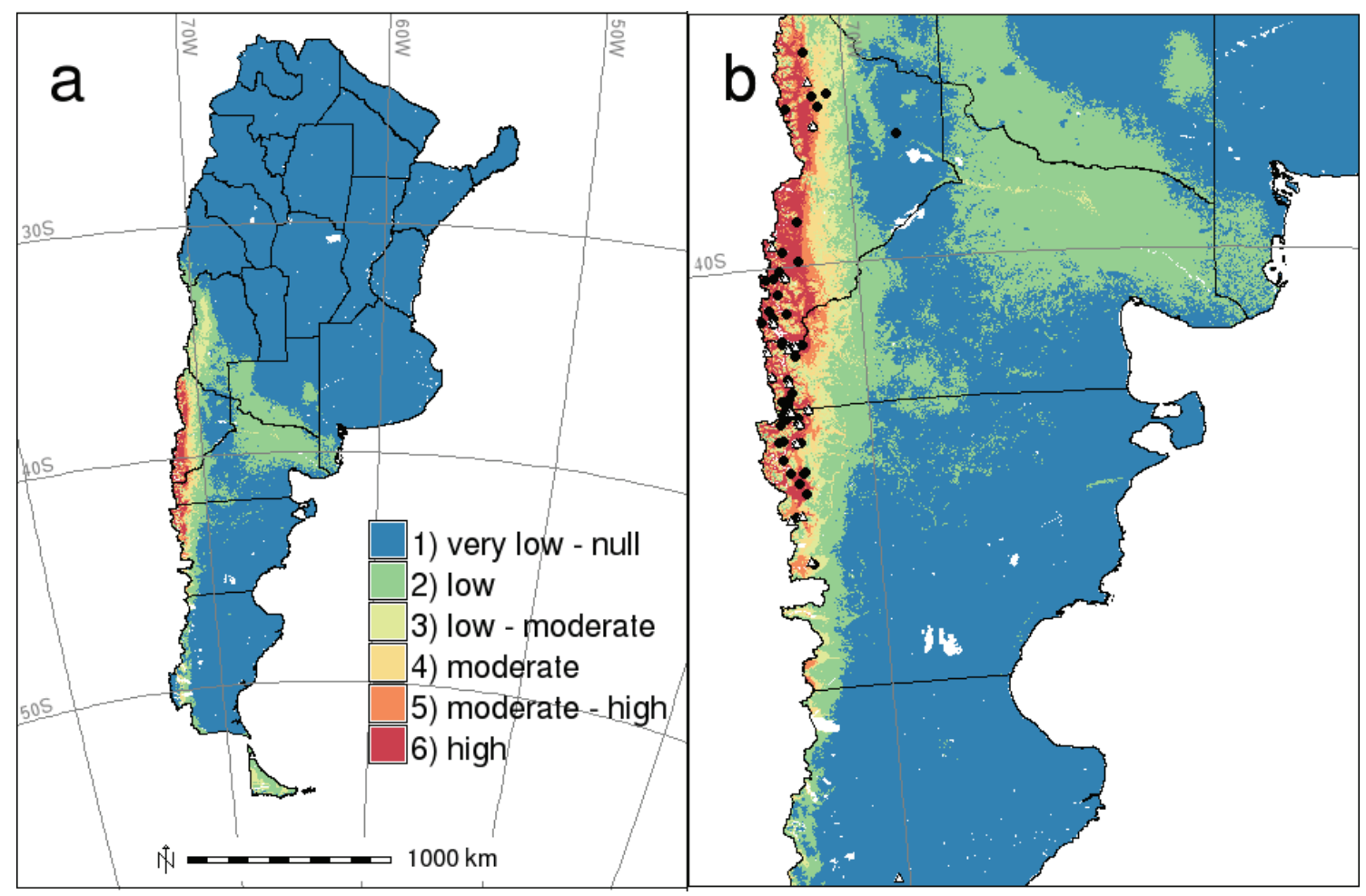




\section{Discussion}

Sites with confirmed cases of HPS (caused by ANDV) in Patagonia were mostly concentrated in the area with the highest probability of occurrence; a very narrow strip along the Andes range from northern Neuquén to central Chubut province. The highest infection probabilities for humans appeared, then, to be concentrated in this narrow area of $\sim 23,500 \mathrm{~km}^{2}$ in the Andean region of sub-Antarctic forests. In general, sites with a higher probability of HPS occurrence in southern Argentina were characterized by high annual mean precipitation $(\sim 1,000 \mathrm{~mm}$ on average, ranging from 500 in the eastern part to $2,000 \mathrm{~mm}$ in the west), but dry summers (from 40 to $250 \mathrm{~mm}$ ), very low percentages of bare soil $\left(10 \%\right.$ on average) and low temperatures in the coldest month (from -3.6 to $\left.0.8{ }^{\circ} \mathrm{C}\right)$. Habitats with these environmental features coincide mostly with sub-Antarctic forests dominated by Nothofagus species and Austrocedrus chilensis and shrublands, where colilargo abundance, as well as ANDV prevalence are known to be the highest [31-34,39]. Therefore, the highest abundances of hosts or the highest probabilities of occurrence (which would allow virus persistence and transmission given the assumed higher connectivity among populations) would be good indicators of the highest levels of transmission risk.

Although both models (GLM and MaxEnt) were highly satisfactory in terms of AUC, the output of the MaxEnt model was more precise and showed better performance in the accuracy and error measures considered. Two other reasons for choosing MaxEnt included: (1) it extends the moderate-high probability of occurrence of HPS until southern Santa Cruz and Tierra del Fuego, consistent with previous records $[45,46]$; and (2) it correctly predicted low occurrence probabilities in areas with no records for ANDV.

The models fitted here assume a static distribution of the host species and disease cases (i.e., in equilibrium with the environment), an assumption usually permitted for modeling purposes. Previous studies, however, have pointed out a tendency towards lower precipitation and higher temperatures for southern South America [47,48]. Although we accept that there may be limitations in using climate data averaged over a 50-year period, it has been shown that most of colilargos' actual distribution would remain unchanged unless climatic tendencies were double those observed [49]. We may assume, therefore, that our models and maps constitute a good representation of current and future disease distribution.

The emergence of human diseases has often been found to be more spatially restricted than the distribution of the reservoir host [50,51]. This seems to be the case for HPS in southern Argentina, too. In fact, the area with the highest probability for HPS occurrence represents $28 \%$ of the highest probability area in the $O$. longicaudatus distribution map (Figure 3). This particular area has a quite low population density (4.5 inhabitants per $\mathrm{km}^{2}$ on average; from 0.8 to 24.7 ; Instituto Nacional de Estadística y Censos, Argentina) [52] and it is characterized by cities of mean urban development (mainly touristic cities), little towns with undefined boundaries and a rural population. The economic activity is mostly related to tourism, crafts and fruit production [24].

Other factors have to be searched regarding the variation of human susceptibility or exposure. In fact, it has been observed that the disease is more frequent in young (21-30 years old) active males [26]. Aside from contact with previous HPS case-patients, it was reported that the most frequent exposure factors for HPS in Patagonia were related to rural work (general work on farms, preparing 
land for cultivation, clearing weeds, planting and harvesting and cleaning out barns or other outbuildings) and activities in natural environments (recreational activities or tourism) [26]. There is a particular activity that poses quite a high risk of infection: from March to May, local inhabitants collect sweet briar fruits for jam making and the cosmetic industry. Shrublands dominated by this plant have shown the highest abundances of colilargos, and infection was more frequently detected in this kind of habitat $[33,34]$. In addition, the fruits of sweet briar are one of the most common food items of colilargos year-round [53]. On the other side, variation in the hazard, represented by the infection prevalence of the rodent host, may be due to: (1) the requirement for threshold population densities to sustain infection in the reservoir [54,55]; (2) differences in virus pathogenicity and/or host immunity; (3) the existence of unrecognized cryptic host species that might not support infection [11]; or (4) demographic differences in the human population.

Infected $O$. longicaudatus have been captured along the Andes range in Neuquén, Río Negro and Chubut provinces in Argentina [31-34,39]. Most cases seem to occur in forest or shrubland habitats (especially those highly covered with the invasive Rosa rubiginosa), where the highest host abundance and virus prevalence have been recorded [31-34,39]. Besides, infected mice have also been captured in shrubby peridomestic settings [33] and sylvan areas of steppe in Chubut province [34]. In fact, the southernmost HPS case recorded in Argentina (48 $46^{\prime} 1.2^{\prime \prime} \mathrm{S} ; 70^{\circ} 15^{\prime} 0.0^{\prime \prime} \mathrm{W}$ ) occurred in a steppe-like habitat [56]. If we take this into account, the steppe areas that are close to forests and sum up the moderate and high HPS risk classes (classes 4, moderate, 5, moderate-high, and 6, high risk), the total risk area in southern Argentina adds up to $58,000 \mathrm{~km}^{2}$ (more than double the high risk area). The population under risk in this area is about 300,000 people (2010 population census, Instituto Nacional de Estadística y Censos, Argentina) [52], a number that increases considerably in the summer months, due to tourism (one of the main economic activities of the region) [24].

In this sense, we understand that the delineation of high risk areas is always relevant, but we also sustain that monitoring should be carried out in those transition areas of moderate/low probabilities that, in light of dramatic environmental or demographic changes, may shift their risk status. For the case of HPS in Patagonia, these are quite unpopulated areas eastwards of the Andes range (most of the human population is concentrated on the west, where the hazard is higher), but that may not be the case for other regions of Argentina or for other diseases in general, where, in the face of environmental or demographic changes, the risk level may increase. It may be worth including demographic variables into models in case they are correlated or confounded with some significant environmental feature [57] or adjusting the hazard by human population density.

Some variables identified as the best predictors in our models implicitly include a seasonal dimension that it is not explicitly considered in the response variable. However, this is where, to our understanding, the temporal aspect of the trophic cascade translates into the spatial distribution of the disease modeled by SDM. Variables retained in models for HPS human cases are consistent with factors affecting the temporal dynamics of hosts (i.e., minimum temperature, precipitation of the warmest season) [38] and, consequently, their spatial distribution, which will then influence the occurrence and distribution of the disease. These same variables were found to be significant for host distribution at different spatial scales $[19,34,45]$. We may infer, therefore, that these variables reflect factors that influence host dynamics and distribution in areas of high transmission and, consequently, determine the number of human cases, as stated in the trophic cascade model. For example, let us 
consider the precipitation of the warmest season. We know that the abundance of the host is quite low in summer, and infection prevalence high; higher levels of precipitation would imply more primary productivity (food and refuge). This would favor reproductive activity and would translate into higher abundance the following autumn-winter period. Higher abundance would imply higher transmission among rodents and higher probabilities of transmission to humans [12].

Disease transmission systems represent complex interactions among multiple species (e.g., vectors, hosts, pathogens) and different options exist regarding how they should be analyzed and modeled. Traditionally, methodologies for evaluating the geographic risk of disease transmission have focused on the overall distribution of cases as an epi-phenomenon. Though useful as a primary tool, this approach is only able to identify broad general trends and patterns, giving an overall picture of the ecology of the transmission chain [58]. An alternative, however, would be to model each component species in the transmission system and then assemble them into a geographic picture of the transmission system, as we intend to do in the present work. In our view, the combination of predictive distribution maps of the reservoir host and disease cases, which reflect the actual exposure of humans to the virus, represents an improvement and a step forward in the understanding of the risk factors that need to be considered in regional/national-scale risk forecasting and mapping. Therefore, we propose thematic maps, such as the one obtained here, as basic tools, allowing public health authorities to focus surveillance efforts and commonly scarce resources for prevention and control actions in vast areas, like southern Argentina.

\section{Materials and Methods}

\subsection{Hantavirus Pulmonary Syndrome Data}

Time series data on HPS confirmed cases caused by ANDV in southern Argentina was provided by the Health Ministries of Neuquén, Río Negro and Chubut provinces, covering the period 1995-2009. Further data on confirmed cases was obtained from a literature review [55]. Using information regarding potential infection sites and residence localities, latitude and longitude coordinates were assigned to sites with confirmed cases. The set of coordinates were mostly obtained from the National Geographic Institute GIS database (Instituto Geográfico Nacional, Argentina) [59] through searching for the corresponding place/locality name. HPS localities were considered just once when more than one case was recorded at the same site and when secondary transmission was confirmed or suspected. We deleted sites that were less than $3 \mathrm{~km}$ apart to avoid auto-correlation issues. Since the estimation of the potential distribution requires absences located farther apart in the geographic and/or environmental space and we only had "presence" data, we randomly selected localities without confirmed cases of HPS (by ANDV) all over the country [60]. We treated these points as real absences, since HPS declaration is mandatory, and we only used confirmed cases (through laboratory antibody tests). The database consisted, then, of 61 different localities with confirmed cases and 186 points without cases, following common approaches [60,61]. A randomly selected subset of locations (20\% of presences and absences) was withheld for validation studies. Records of HPS localities were imported into a GIS using the free and open source software, GRASS GIS 7.0 [62,63]. 


\subsection{Environmental Data}

Data layers for topography, climate and land cover were compiled for Argentina: Altitude and climatic data layers as 19 bioclimatic variables (of $\sim 1 \mathrm{~km}^{2}$ of spatial resolution) were drawn from the WorldClim data set [64]. Land cover data was drawn from the Vegetation Continuous Fields collection (VCFMOD44B, collection 3), which contains proportional estimates for vegetative cover types: woody vegetation, herbaceous vegetation and bare ground [65]. The product was aggregated from an initial $0.5 \mathrm{~km}$ to $1 \mathrm{~km}$ pixel length to match the resolution of the climatic variables by average value resampling in GRASS GIS. Land cover data from 5 different classification schemes derived from MODIS (Moderate Resolution Imaging Spectroradiometer) sensor imagery (MOD12Q1) were used to estimate the proportion of cases occurring in each type of vegetation cover [66].

\subsection{Spatial and Statistical Modeling}

To characterize the distribution of HPS caused by ANDV, two modeling approaches were compared: generalized linear models (GLM) with binomial error [67] and the Maximum Entropy algorithm (MaxEnt) [68-70]. We first performed an exploratory analysis comparing environmental variables between sites with and without HPS cases with Kruskal-Wallis tests. We also conducted univariate binomial GLMs to determine the association between HPS occurrence and altitude, climate and land cover. Variables that did not differ between sites with and without HPS or that were not significant in univariate GLMs were not considered for further analysis. The significance of variables inside models was evaluated with $t$-tests. Variance inflation factors (VIFs) and pairwise Pearson correlation coefficients were computed to evaluate collinearity among the independent variables. Variables with VIFs lower than 10 (and/or that yielded an average VIF of 5) were retained. A multimodel inference approach based on Akaike's information criterion (AIC) was used, and the resulting best model (lowest AIC) was applied in a GIS to extrapolate the predicted likelihood of occurrence across the entire area of concern and to draw inferences. R 3.0.1 [71] and GRASS GIS 7.0 [62,63] were used for modeling and mapping, respectively. A Moran test was applied to the residuals of this model to assess whether the unexplained variation was randomly distributed (Software Passage version 2.0) [72].

The MaxEnt algorithm was applied using the same combination of predictor variables as in the best GLM model. It was run using MaxEnt software, version 3.3.3k [68-70], with the SWD format ("samples with data"), which allows for the inclusion of both presence and absence data. We used a logistic map as output with values ranging from 0 to 1 . All other MaxEnt software parameters were maintained at default settings.

As recommended by Vaughan and Ormerod [73], we assessed the predictive performance of GLM and MaxEnt models with both threshold-dependent and -independent measures using the training dataset, to provide both a general assessment of performance and one specific to particular thresholds, and to obtain a more accurate picture of the predictive behavior of the models. Using receiver operating characteristic (ROC) curves, we assessed the overall discrimination ability of each model on the basis of the area under the ROC curve (AUC) as the threshold-independent measure. However, as predictive modeling also requires a threshold probability at which to accept the occurrence of the 
entity being modeled, we complemented the former evaluation with a threshold-dependent approach, which entails selecting a threshold for converting probabilities of occurrence into binary data [74-76]. We compared different criteria for threshold selection [77] using the package, SDMTools 1.1-13 in the R Language and Environment for Statistical Computing [78]. The criteria considered were: minimum occurrence prediction, mean occurrence prediction, $10 \%$ omission, sensitivity = specificity, maximum sensitivity + specificity, maximum kappa, maximum proportion of presence and absence records correctly identified and min-ROC (plot distance; the threshold value or range of values where the ROC curve is closest to point 0,1$)$. For each threshold, we obtained a binary map and confusion matrix that allowed us to depict the modeled spatial distribution and to provide other estimates of model accuracy (Table 4) based on comparing observed versus predicted presences and absences [75,79-81]. Finally, the test dataset was used to compare the performance of the models using only a threshold-independent measure. ROC and AUC were estimated using the package, ROCR, version 1.0-5 for R [82].

Table 4. Threshold-dependent measures used for assessing the predictive performance of models. TP, the number of presence points correctly classified as present; TN, the number of absence points correctly classified as absent; FP, the number of actual absence points classified as present; FN, the number of actual presence points classified as absent; P, the total number of actual presences; $\mathrm{N}$, the total number of actual absences.

\begin{tabular}{ccc}
\hline Performance measure & Definition & Formula \\
\hline Sensitivity (True positive rate) & Proportion true presences correctly predicted & TP/P \\
Specificity (True negative rate) & Proportion true absences correctly predicted & TN/N \\
False positive rate & & FP/N \\
False negative rate & & FN/P \\
Positive predictive value (Precision) & Percentage of predicted presences that were real & $\mathrm{TP} /(\mathrm{TP}+\mathrm{FP})$ \\
Negative predictive value & Percentage of predicted absences that were real & $\mathrm{TN} /(\mathrm{TN}+\mathrm{FN})$ \\
\hline
\end{tabular}

\subsection{HPS Risk Mapping: Integration with Previous Potential Distribution Map of Host}

The existing continuous potential distribution map for rodent host [19] and the HPS distribution map obtained in the present study were reclassified into four intervals reflecting levels of risk (in general, the higher the probability, the higher the risk). For the reclassification, we considered the thresholds estimated previously (as described above) and the analysis of the distribution of predicted probabilities for the presence and absence points in the training datasets of both host and human cases. Maps for reservoir host and HPS were then added up to represent the different categories of risk considering the combination of host and HPS presence/absence and assuming the highest risk to occur, where both $O$. longicaudatus and HPS cases showed the highest probability of presence (Figure 5). 
Figure 5. Schematic representation of the methodological workflow.

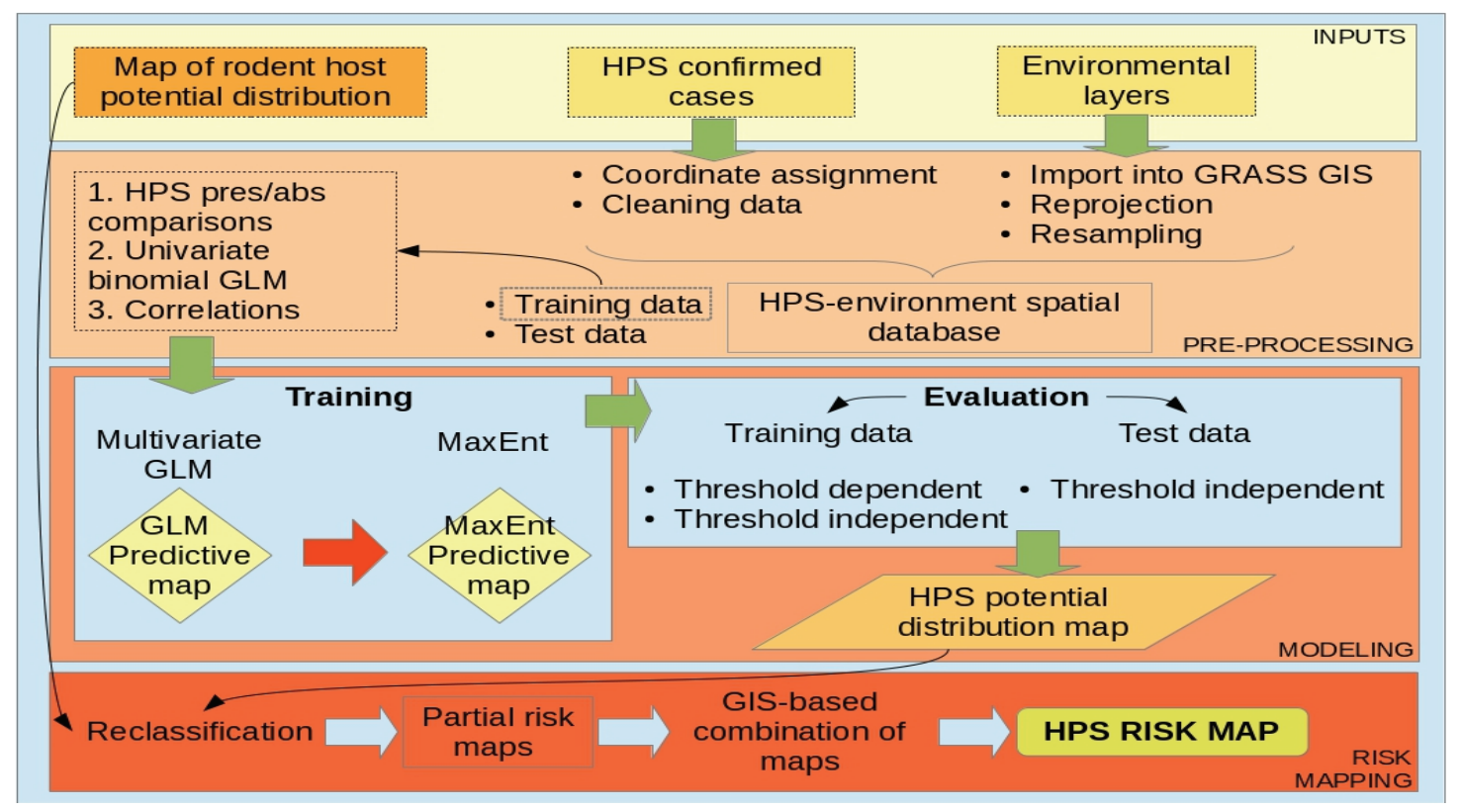

\section{Conclusions}

The present analysis of HPS and $O$. longicaudatus occurrence in southern Argentina contributes to a better understanding of the system and the distribution of transmission risk. Although HPS is a relatively rare disease in Argentina (more than 1,000 cases between 1995 and 2009 over all of the country) [74] and cases provoked by ANDV constitute $16.5 \%$ of the cases declared in the country [45], the disease is among the most pathogenic ( $\sim 50 \%$ lethality) of human viral infections. ANDV is the only hantavirus that presents the ability to be transmitted among humans. As more cases are recognized and risk factors are better identified, it will be possible to enhance surveillance efforts and to evaluate prevention measures. We emphasize and highlight that when human-to-human transmission occurs, there is the need for improving surveillance.

\section{Acknowledgments}

This research was made possible by grants from the Fondo para la Investigación Científica y Tecnológica (FONCYT) and Consejo Nacional de Investigaciones Científicas y Técnicas (CONICET). This article was written as a result of an internship of V.A. funded by Comisión Nacional de Actividades Espaciales (CONAE) and Agenzia Spaziale Italiana-Ministero degli Affari Esteri (ASI-MAE) at the Fondazione Edmund Mach, Research and Innovation Center, Department of Biodiversity and Molecular Ecology, Animal Ecology group and the GIS and Remote Sensing Unit (http://gis.cri.fmach.it/), Italy. V.A. thanks CONAE and ASI-MAE (Italy) for the financial assistance and the host institution for a great working environment and facilities. We are grateful to the Health Ministries of Neuquén, Río Negro and Chubut provinces (Argentina) for providing us with human case data and to the NASA Land Processes Distributed Active Archive Center (LP DAAC) for making the MODIS data available. We are also grateful to two anonymous reviewers who provided valuable comments and suggestions on an earlier version of the manuscript. 


\section{Conflicts of Interest}

The authors declare no conflict of interest.

\section{References and Notes}

1. Enria, D.A.M.; Levis, S.C. Zoonosis virales emergentes: Las infecciones por Hantavirus. Introducción e Historia (in Spanish). Rev. Sci. Tech. Off. Int. Epiz. 2004, 23, 595-611.

2. Hjelle, B.; Torres-Pérez, F. Hantaviruses in the Americas and their role as emerging pathogens. Viruses 2010, 2, 2559-2586.

3. Kang, H.J.; Bennett, S.N.; Hope, A.G.; Cook, J.A.; Yanagihara, R. Shared ancestry between a newfound mole-borne hantavirus and hantaviruses harbored by cricetid rodents. J. Virol. 2011, $85,7496-7503$.

4. Song, J.W.; Baek, L.J.; Schmaljohn, C.S.; Yanagihara, R. Thottapalayam virus, a prototype shrewborne hantavirus. Emerg. Infect. Dis. 2007, 13, 980-985.

5. Calisher, C.H.; Childs, J.E.; Field, H.E.; Holmes, K.V.; Schountz, T. Bats: Important reservoir hosts of emerging viruses. Clin. Microbiol. Rev. 2006, 19, 531-545.

6. Jonsson, C.B.; Tadeu, L.; Figueiredo, M.; Vapalahti, O. A global perspective on hantavirus: Ecology, epidemiology and disease. Clin. Microbiol. Rev. 2010, 23, 412-441.

7. Glass, G.E.; Childs, J.E.; Korch, G.W.; LeDuc, J.W. Association of intraspecific wounding with hantaviral infection in wild rats (Rattus norvegicus). Epidemiol. Infect. 1988, 101, 459-472.

8. Childs, J.E.; Ksiazek, T.G.; Spiropoulou, C.F.; Krebs, J.W.; Morzunov, S.; Maupin, G.O.; Rollin, P.E.; Sarisky, J.; Enscore, R.E. Serologic and genetic identification of Peromyscus maniculatus as the primary rodent reservoir for a new hantavirus in the southwestern United States. J. Infect. Dis. 1994, 169, 1271-1280.

9. Botten, J.; Mirowsky, K.; Ye, C.Y.; Gottlieb, K.; Saavedra, M.; Ponce, L.; Hjelle, B. Shedding and intracage transmission of Sin Nombre hantavirus in the deer mouse (Peromyscus maniculatus) model. J. Virol. 2002, 76, 7587-7594.

10. Padula, P.; Figueroa, R.; Navarrete, M.; Pizarro, E.; Cadiz, R.; Bellomo, C.; Jofre, C.; Zaror, L.; Rodriguez, E.; Murua, R. Transmission study of Andes hantavirus infection in wild sigmodontine rodents. J. Virol. 2004, 78, 11972-11979.

11. Mills, J.; Childs, J.E. Ecologic studies of rodent reservoirs: Their relevance for human health. Emerg. Infect. Dis. 1998, 4, 529-537.

12. Mills, J. The role of rodents in emerging human disease: Examples from the hantaviruses and arenaviruses. In Ecologically-Based Rodent Management; Singleton, G.R., Hinds, L.A., Leirs, H., Zhang, Z., Eds.; Arrawang Communication Group: Canberra, Australia, 1999; pp. 134-160.

13. Yates, T.; Mills, J.; Parmenter, C.; Ksiazek, T.; Parmenter, R.; Vande Castle, J.; Calisher, C.; Nichol, S.; Abbott, K.; et al. The ecology and evolutionary history of an emergent disease: Hantavirus Pulmonary Syndrome. Bioscience 2002, 52, 989-998.

14. Parmenter, R.; Yadav, E.; Parmenter, C.; Ettestad, P.; Gage, K. Incidence of plague associated with increased winter-spring precipitation in New Mexico. Am. J. Trop. Med. Hyg. 1999, 61, 814-821. 
15. Linard, C.; Lamarque, P.; Heyman, P.; Ducoffre, G.; Luyasu, V.; Tersago, K.; Vanwambeke, S.O.; Lambin, E.F. Determinants of the geographic distribution of Puumala virus and Lyme borreliosis infections in Belgium. Int. J. Health Geogr. 2007, 2, 6-15.

16. Vanwambeke, S.O.; Šumilo, D.; Bormane, A.; Lambin, E.F.; Randolph, S.E. Landscape predictors of tick-borne encephalitis in Latvia: Land cover, land use, and land ownership. Vector Borne Zoonotic Dis. 2010, 10, 497-506.

17. Glass, G.; Cheek, J.; Patz, J.; Shields, T.; Doyle, T.; Thoroughman, D.; Hunt, D.; Enscore, R.; Gage, K.; Irland, C.; et al. Using remotely sensed data to identify areas at risk for Hantavirus Pulmonary Syndrome. Emerg. Infect. Dis. 2000, 6, 238-247.

18. Goodin, D.G.; Koch, D.E.; Owen, R.D.; Chu, Y.; Hutchinson, J.M.S.; Jonsson, C.B. Land cover associated with hantavirus presence in Paraguay. Glob. Ecol. Biogeogr. 2006, 15, 519-527.

19. Andreo, V.; Glass, G.; Shields, T.; Provensal, C.; Polop, J. Modeling potential distribution of Oligoryzomys longicaudatus, the Andes Virus (Genus: Hantavirus) reservoir, in Argentina. EcoHealth 2011, 3, 332-348.

20. Pearson, R.G.; Dawson, T.P. Predicting the impacts of climate change on the distribution of species: Are bioclimate envelope models useful? Glob. Ecol. Biogeogr. 2003, 12, 361-371.

21. Elith, J.; Graham, C.H.; Anderson, R.P.; Dudik, M.; Ferrier, S.; Guisan, A.; Hijmans, R.J.; Huettmann, F.; Leathwick, J.R.; Lehmann, A.; et al. Novel methods improve prediction of species' distributions from occurrence data. Ecography 2006, 29, 129-151.

22. Elith, J.; Leathwick, J.R. Species Distribution Models: Ecological explanation and prediction across space and time. Ann. Rev. Ecol. Evol. Syst. 2009, 40, 677-697.

23. Franklin, J. Mapping Species Distributions. Spatial Inference and Prediction; Cambridge University Press: New York, NY, USA, 2010; p. 320.

24. Sosa-Estani, S.; Salomón, O.D.; Gómez, A.O.; Esquivel, M.L.; Segura, E.L. Diferencias regionales y Síndrome Pulmonar por Hantavirus (enfermedad emergente y tropical en Argentina) (in Spanish). Cad. Saude Publica 2001, 17, 47-57.

25. Padula, P.J.; Martinez, V.P.; Bellomo, C.; Maidana, S.; San Juan, J.; Tagliaferri, P.; Bargardi, S.; Vazquez, C.; Colucci, N.; Estevez, J.; et al. Pathogenic hantaviruses, northeastern Argentina and eastern Paraguay. Emerg. Infect. Dis. 2007, 13, 1211-1214.

26. Martinez, V.P.; Bellomo, C.M.; Cacace, M.L.; Suárez, P.; Bogni, L.; Padula, P.J. Hantavirus pulmonary syndrome in Argentina, 1995-2008. Emerg. Infect. Dis. 2010, 16, 1853-1860.

27. Lopez, N.; Padula, P.; Rossi, C.; Lazaro, M.E.; Franze-Fernandez, M.T. Genetic identification of a new hantavirus causing severe pulmonary syndrome in Argentina. Virology 1996, 219, 1-4.

28. Levis, S.; Morzunov, S.; Rowe, J.; Enria, D.; Pini, N.; Calderón, G.; Sabattini, M.; St Jeor, S. Genetic diversity and epidemiology of hantaviruses in Argentina. J. Infect. Dis. 1998, 177, 529-538.

29. Murúa, R.; Gonzalez, L.A. Microhabitat selection in two Chilean cricetid rodents. Oecologia 1982, 52, 12-15.

30. Pearson, O.P. Characteristics of a mammalian fauna from forests in Patagonia, Southern Argentina. J. Mammal. 1983, 64, 476-492.

31. Larrieu, E.; Herrero, E.; García Cachau, M.; Labanchi, J.L.; Mancini, S.; Padula, P.; Cantoni, G.; Cavagion, L.; Alvarez, E.; Bruni, M.; et al. Seroprevalencia de hantavirus en roedores y casos humanos en el sur de Argentina (in Spanish). Rev. Bras. Epidemiol. 2003, 6, 68-75. 
32. Piudo, L.; Monteverde, M.; Gonzalez Capria, S.; Padula, P.; Carmanchahi, P. Distribution and abundance of sigmodontine rodents in relation to hantavirus in Neuquén, Argentina. J. Vector Ecol. 2005, 30, 119-125.

33. Polop, F.J.; Provensal, M.C.; Pini, N.; Levis, S.C.; Priotto, J.W.; Enría, D.; Calderón, G.E.; Costa, F.; Polop, J.J. Temporal and spatial host abundance and prevalence of Andes Hantavirus in Southern Argentina. EcoHealth 2010, 7, 176-184.

34. Andreo, V.; Provensal, M.C.; Levis, S.C.; Pini, N.; Enria, D.; Polop, J. Summer-autumn distribution and abundance of the hantavirus host, Oligoryzomys longicaudatus, in northwestern Chubut, Argentina. J. Mammal. 2012, 93, 1559-1568.

35. Jaksic, F.M.; Lima, M. Myths and facts on ratadas: Bamboo blooms, rainfall peaks and rodent outbreaks in South America. Austral Ecol. 2003, 28, 237-251.

36. Sage, R.D.; Pearson, O.P.; Sanguinetti, J.; Pearson, A.K. Ratada 2001: A rodent outbreak following the flowering of bamboo (Chusquea culeou) in Southwestern Argentina. In The Quintessential Naturalist; Kelt, D., Kaspin, D., Eds.; University of California Press: Berkeley, CA, USA, 2007; pp. 177-224.

37. Pearson, O.P. A perplexing outbreak of mice in Patagonia, Argentina. Stud. Neotrop. Fauna Environ. 2002, 37, 187-200.

38. Murua, R.; Gonzalez, L.A.; Lima, M. Population dynamics of rice rats (a Hantavirus reservoir) in southern Chile: Feedback structure and non-linear effects of climatic oscillations. Oikos 2003, 102, 137-145.

39. Cantoni, G.; Padula, P.; Calderón, G.; Mills, J.; Herrero, E.; Sandoval, P.; Martinez, V.; Pini, N.; Larrieu, E. Seasonal variation in prevalence of antibody to hantaviruses in rodents from southern Argentina. Trop. Med. Int. Health 2001, 6, 811-816.

40. Yadón, Z. Epidemiología del síndrome pulmonar por hantavirus en la Argentina (1991-1997) (in Spanish). Medicina 1998, 58, 25-26.

41. Wells, R.; Sosa, S.; Yadón, Z.; Enría, D.; Padula, P.; Pini, N.; Mills, J.N.; Peters, C.J.; Segura, E.L. An unusual hantavirus outbreak in south Argentina: Person-to-person transmission? Emerg. Infect. Dis. 1997, 3, 171-174.

42. Padula, P.; Edelstein, A.; Miguel, S.; Lopez, M.; Rossi, C.; Rabinovish, R. Hantavirus pulmonary syndrome outbreak in Argentina: Molecular evidence of person-to-person transmission of Andes virus. Virology 1998, 15, 323-330.

43. Martinez, V.P.; Bellomo, C.; San Juan, J.; Pinna, D.; Forlenza, R.; Elder, M.; Padula, P.J. Person-to-person transmission of Andes virus. Emerg. Infect. Dis. 2005, 11, 1848-1853.

44. Porcasi, X.; Calderon, G.; Lamfri, M.; Gardenal, N.; Polop, J.; Sabattini, M.; Scavuzzo, M. The use of satellite in modeling population dynamics and prevalence of infection in the rodent reservoir of Junin virus. Ecol. Model. 2005, 185, 437-449.

45. Carbajo, A.E.; Pardiñas, U.F.J. Spatial distribution model of a hantavirus reservoir, the long-tailed colilargo (Oligoryzomys longicaudatus), in Argentina. J. Mammal. 2007, 88, 1555-1568.

46. Belmar-Lucero, S.; Godoy, P.; Ferres, M.; Vial, P.; Palma, R.E. Range expansion of Oligoryzomys longicaudatus (Rodentia: Sigmodontinae) in Patagonian Chile and first record of Hantavirus in the region. Rev. Chil. Hist. Nat. 2009, 82, 265-275. 
47. Haylock, M.R.; Peterson, T.; Sousa, J.R.A.D.; Alves, L.M.; Ambrizzi, T.; Baez, J.; Barbosa, J.I.; Barros, V.R.; Berlato, M.A.; Bidegain, M.; et al. Trends in total and extreme South American rainfall in 1960-2000 and links with sea surface temperature. J. Climate 2006, 19, 1490-1512.

48. Rusticucci, M.; Penalba, O. Interdecadal changes in the precipitation seasonal cycle over Southern South America and their relationship with surface temperature. Clin. Res. 2000, 16, 1-15.

49. Carbajo, A.E.; Vera, C.; González, P.L.M. Hantavirus reservoir Oligoryzomys longicaudatus spatial distribution sensitivity to climate change scenarios in Argentine Patagonia. Int. J. Health Geogr. 2009, 8, 44.

50. Schmaljohn, C.; Hjelle, B. Hantaviruses: A global disease problem. Emerg. Infect. Dis. 1997, 3, 95-104.

51. Olsson, G.E.; Dalerum, F.; Hörnfeldt, B.; Elgh, F.; Palo, T.R.; Juto, P.; Ahlm, C. Human hantavirus infections, Sweden. Emerg. Infect. Dis. 2003, 9, 1395-1401.

52. Instituto Nacional de Estadística y Censos (INDEC). Censo nacional de población, hogares y viviendas 2010. Censo del Bicentenario: resultados definitivos (in Spanish). Buenos Aires, Argentina, 2012, p. 378. Available online: http://www.indec.gov.ar/ (accessed on 23 December 2013).

53. Sbriller, A.; Sepúlveda, L. La Rosa Mosqueta, el colilargo patagónico y el Hantavirus (in Spanish). Desde la Patagonia 2007, 5, 18-22.

54. Calisher, C.H.; Mills, J.N.; Sweeney, W.P.; Choate, J.R.; Sharp, D.E.; Canestorp, K.M.; Beaty, B.J. Do unusual site-specific population dynamics of rodent reservoirs provide clues to the natural history of hantaviruses? J. Wildl. Dis. 2001, 37, 280-288.

55. Madhav, N.K.; Wagoner, K.D.; Douglass, R.J.; Mills, J.N. Delayed density-dependent prevalence of Sin Nombre virus antibody in Montana deer mice (Peromyscus maniculatus) and implications for human disease risk. Vector Borne Zoonotic Dis. 2007, 7, 353-364.

56. Bellomo, C.; Nudelman, J.; Kwaszka, R.; Vazquez, G.; Cantoni, G.; Weinzettel, B.; Larrieu, E.; Padula, P. Expansión geográfica del Síndrome Pulmonar por Hantavirus en la Argentina: Informe del caso más austral (in Spanish). Medicina (Buenos Aires) 2009, 69, 647-650.

57. Carbajo, A.E.; Cardo, M.V.; Vezzani, D. Is temperature the main cause of dengue rise in non-endemic countries? The case of Argentina. Int. J. Health Geogr. 2012, 11, 26.

58. Peterson, A.T. Ecological niche modelling and understanding the geography of disease transmission. Vet. Ital. 2007, 43, 393-400.

59. SIGN. Sistema de Información Geográfica del Instituto Geográfico Nacional de la República Argentina. Available online: http://sig.ign.gob.ar/ (accessed on 23 December 2013).

60. Lobo, J.M.; Jimenez-Valverde, A.; Hortal, J. The uncertain nature of absences and their importance in Species Distribution Modelling. Ecography 2010, 33, 103-114.

61. Wisz, M.S.; Guisan, A. Do pseudo-absence selection strategies influence Species Distribution Models and their predictions? An information-theoretic approach based on simulated data. BMC Ecol. 2009, 13, 1-13.

62. GRASS Development Team. Geographic Resources Analysis Support System (GRASS) Software, Version 7; Open Source Geospatial Foundation: San Michele all'Adige, Italy, 2013. Available online: http://grass.osgeo.org/ (accessed on 21 Dec 2013). 
63. Neteler, M.; Bowman, M.H.; Landa, M.; Metz, M. GRASS GIS: A multi-purpose open source GIS. Environ. Model. Softw. 2012, 31, 124-130.

64. Hijmans, R.J.; Cameron, S.E.; Parra, J.L.; Jones, P.G.; Jarvis, A. Very high resolution interpolated climate surfaces for global land areas. Int. J. Climatol. 2005, 25, 1965-1978.

65. Hansen, M.; de Fries, R.S.; Townshend, J.R.G.; Carroll, M.; Dimiceli, C.; Sohlberg, R.A. Global percent tree cover at a spatial resolution of 500 meters: First results of the MODIS vegetation continuous fields algorithm. Earth Interact. 2003, 7, 1-15.

66. Friedl, M.A.; McIver, D.K.; Hodges, J.C.F.; Zhang, X.; Muchoney, D.; Strahler, A.H.; Woodcock, C.E.; Gopal, S.; Schnieder, A.; Cooper, A.; et al. Global land cover from MODIS: Algorithms and early results. Remote Sens. Environ. 2002, 83, 135-148.

67. Zuur, A.F.; Ieno, E.N.; Walker, N.; Saveliev, A.; Smith, G. Mixed Effects Models and Extensions in Ecology with R; Springer: New York, NY, USA, 2009; p. 574.

68. Phillips, S.J.; Anderson, R.P.; Schapire, R.E. Maximum entropy modeling of species geographic distributions. Ecol. Model. 2006, 190, 231-259.

69. Elith, J.; Phillips, S.J.; Hastie, T.; Dudík, M.; Chee, Y.E.; Yates, C.J. A statistical explanation of MaxEnt for ecologists. Divers. Distrib. 2011, 17, 43-57.

70. Merow, C.; Smith, M.J.; Silander, J.A. A practical guide to MaxEnt for modeling species' distributions: What it does, and why inputs and settings matter. Ecography 2013, 36, 1-12.

71. R Core Team. R: A Language and Environment for Statistical Computing. In $R$ Foundation for Statistical Computing; Vienna, Austria, 2013. Available online: http://www.R-project.org/ (accessed on 23 December 2013).

72. Rosenberg, M.S.; Anderson, C.D. PASSaGE: Pattern analysis, spatial statistics and geographic exegesis. Version 2. Methods Ecol. Evol. 2011, 2, 229-232.

73. Vaughan, I.P.; Ormerod, S.J. The continuing challenges of testing species distribution. J. Appl. Ecol. 2005, 42, 720-730.

74. Manel, S. Evaluating presence-absence models in Ecology: The need to account for prevalence. J. Appl. Ecol. 2001, 38, 921-931.

75. Liu, C.; Berry, P.M.; Dawson, T.P.; Pearson, R.G. Selecting thresholds of occurrence in the prediction of species distributions. Ecography 2005, 28, 385-393.

76. Freeman, E.A.; Moisen, G.G. A comparison of the performance of threshold criteria for binary classification in terms of predicted prevalence and kappa. Ecol. Model. 2008, 217, 48-58.

77. Liu, C.; White, M.; Newell, G. Selecting thresholds for the prediction of species occurrence with presence-only data. J. Biogeogr. 2013, 40, 778-789.

78. VanDerWal, J.; Falconi, L.; Januchowski, S.; Shoo, L.; Storlie, C. Species Distribution Modelling Tools: Tools for Processing Data Associated with Species Distribution Modelling Exercises. Package 'SDMTools' 2012. Available online: http://www.rforge.net/SDMTools/ (accessed on 23 December 2013).

79. Anderson, R.P.; Lew, D.; Peterson, A.T. Evaluating predictive models of species' distributions: Criteria for selecting optimal models. Ecol. Model. 2003, 162, 211-232.

80. Lobo, J.M.; Jiménez-Valverde, A.; Real, R. AUC: A misleading measure of the performance of predictive distribution models. Glob. Ecol. Biogeogr. 2008, 17, 145-151. 
81. Hanspach, J.; Kühn, I.; Schweiger, O.; Pompe, S.; Klotz, S. Geographical patterns in prediction errors of species distribution models. Glob. Ecol. Biogeogr. 2011, 20, 779-788.

82. Sing, T.; Sander, O.; Beerenwinkel, N.; Lengauer, T. ROCR: Visualizing classifier performance in R. Bioinformatics 2005, 21, 3940-3941.

(C) 2014 by the authors; licensee MDPI, Basel, Switzerland. This article is an open access article distributed under the terms and conditions of the Creative Commons Attribution license (http://creativecommons.org/licenses/by/3.0/). 